\title{
Predicting phenology of European beech in forest habitats
}

\author{
Urša Vilhar ${ }^{(1)}$, \\ Maarten De Groot ${ }^{(1)}$, \\ Ana Žust ${ }^{(2)}$, \\ Mitja Skudnik ${ }^{(1)}$, \\ Primož Simončič ${ }^{(1)}$
}

\begin{abstract}
Reliable phenological observations are important for studying the response of trees to climate and climate change. National phenological networks were not specifically established to monitor tree phenology within forests, yet they are often used to generalise tree phenological phases at national or regional scales. Our objective was to investigate whether a phenological monitoring network using trees in open areas can accurately predict phenology of European beech (Fagus sylvatica L.) located within forests by using two models: one with correlates of environmental variables and one with interpolated monthly air temperature and sun hours. The first leaf unfolding, general leaf colouring and leaf fall dates from 2004 through 2010 were modelled using data from 47 Slovene National Phenology Network (NPN) stations in open areas and tested on phenological observations within forests using data from the UNECE CRLTAP ICP Forests network. Good agreement was found between predicted and observed first leaf unfolding in the forest, while slightly lower agreement was detected for general leaf colouring and leaf fall. Suggestions for the improvement of national phenological network are discussed in order to better predict beech phenology in forest habitats.
\end{abstract}

Keywords: Leaf Unfolding, Leaf Colouring, Leaf Fall, Modelling, Fagus sylvatica, Slovene National Phenology Network, ICP Forests

on the phenology of certain species, the reliability of observations from phenological monitoring is of paramount importance. In Europe, several long-term phenological monitoring networks have been established and run by the national meteorological services (Vliet et al. 2003, Menzel et al. 2006). The longest records of direct phenological observations are for the flowering of cherry trees Prunus jamasakura in Japan (Aono \& Kazui 2008) and for grape harvests in Western Europe (Chuine et al. 2004). In phenological monitoring networks, different plant and animal groups have been considered, including trees, lower plants, birds and butterflies (Vliet et al. 2003, Parmesan 2006). However, phenological observations of tree phenological phases have proven to be one of the most effective indicators of the impact of climate change (Donnelly et al. 2004). For instance, leaf unfolding is strongly influenced by temperature (Menzel 2000, Menzel et al. 2006, Cufar et al. 2012) and pho-
(1) Slovenian Forestry Institute, Večna pot 2, 1000 Ljubljana (Slovenia); (2) Slovenian Environment Agency, Vojkova 1b, 1000 Ljubljana (Slovenia)

@ Urša Vilhar (ursa.vilhar@gozdis.si)

Received: Aug 20, 2015 - Accepted: Nov 08, 2017

Citation: Vilhar U, De Groot M, Žust A, Skudnik M, Simončič P (2018). Predicting phenology of European beech in forest habitats. iForest 11: 41-47. - doi: 10.3832/ifor1820-010 [online 2018-01-09]

Communicated by: Giorgio Matteucci toperiod (Caffarra \& Donnelly 2011). Apart from the global climate change, site characteristics (altitude, slope, aspect etc.) also have strong influences on temperature and therefore on the phenology of lower plants and trees (Pellerin et al. 2012). Altitude has an inverse relationship with temperature, and therefore phenological events occur later at higher altitudes (Dittmar \& Elling 2006, Cufar et al. 2012, Pellerin et al. 2012). In the Northern Hemisphere, sites with steeper slopes and with south-western aspects become warmer earlier in the season, and consequently, the phenological events there occur earlier than on northern slopes (Pellerin et al. 2012). Furthermore, the effect of local climate is buffered in forests, e.g., the temperature extremes measured outside the forest are not so pronounced within forest stands or in the canopy (Mildrexler et al. 2011). Consequently, the tree phenology within and outside forests could be different.

To describe and model the spatial variability of tree phenological phases at national or regional scales, a phenological monitoring network should maximise the accuracy of the definitions and techniques used and the quality of the data (Vliet et al. 2003). Although many national phenological monitoring networks have their phenological stations equally distributed over altitude, slope, and aspect, most stations are either outside the forest or on its edge (Menzel et al. 2006, Koch et al. 2007). This could have implications for the observed tree phenological phases and the generalisations resulting from these observations at national or regional scales. 


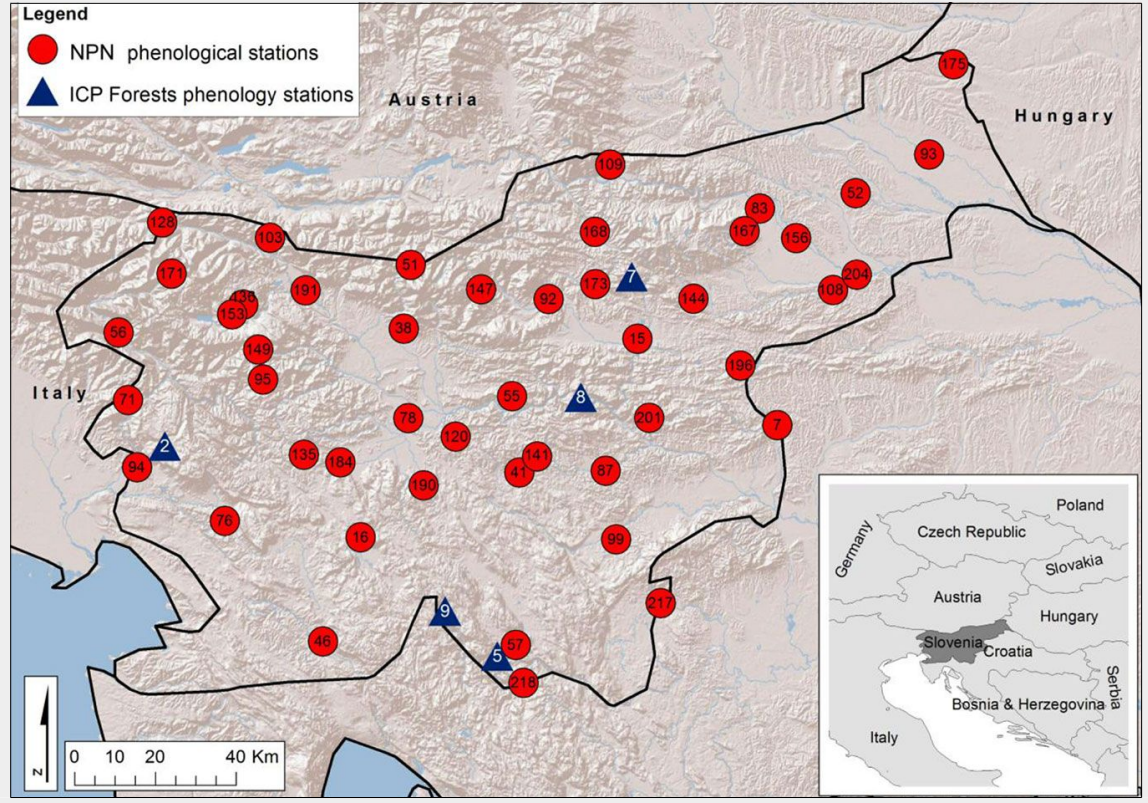

Fig. 1 - Phenological stations of the Slovenian National Phenological Network of the Slovenian Environment Agency (NPN - red cicles) and the Level II phenological monitoring network of the UNECE International Co-operative Programme on Assessment and Monitoring of Air Pollution Effects on Forests (ICP Forests - blue triangles) in Slovenia.

Our objective was to evaluate whether tree phenological phases within forests can be predicted based on tree phenologi cal phases observed at national phenological stations. To this purpose, we used two different models to assess first leaf unfolding, general leaf colouring and leaf fall of European beech (Fagus sylvatica L.) in forests. The models were simple enough to be applied for the major tree species over a large range of possible weather conditions: one model involves correlates of environ mental variables and the other model uses interpolated monthly air temperature and sun hours. The first model is based on onsite data, readily available in any phenological network but with regionally limited ap plication, while the second model is appropriate for wider application (e.g., regional, European), but based on interpolated data. Suggestions for national phenological net work improvements are discussed, aiming to enhance the predictions of tree phenological phases in forests at national or re gional scales.

\section{Methods}

\section{Phenological observations}

We used data on manual phenological observations of the timing of first leaf unfolding, general leaf colouring and leaf fall of beech in Slovenia. Slovenia is characterised by fairly large gradients of climatic factors due to its position between the Alps, the Mediterranean and continental Europe (Cufar et al. 2012, Luis et al. 2014). Consequently, a great variety of forest habitats, from the lowlands to the high mountains, can be found in the country (Kutnar et al.
2002). The phenological stations are distributed throughout Slovenia, with altitudes ranging from 55 to $1050 \mathrm{~m}$ a.s.l. and with different site and climatic characteristics (Fig. 1 - see also Tab. S1 and Tab. S2 in Supplementary material). The period of observation was from 2004 until 2010. The data originated from two monitoring networks, described below.

(A) The monitoring network of the $\mathrm{Na}$ tional Phenological Network of the Slovenian Environment Agency (NPN). The selection of trees and the observations were made in accordance with national guidelines (Zust 2015), which in general follow the World Meteorological Organization (WMO) Guidelines for phenological observations (Koch et al. 2007). Monitoring of different phenological phases, as suggested for perennial plants, was performed on individual adult trees in natural populations. The monitored trees were located in the forest, at forest edge and in open areas. Observations were made at 47 phenological stations on a single tree per station. If one of the selected trees died or was removed, it was replaced with a nearby tree, in accordance with the criteria for phenological monitoring. In spring, the observed period of leaf unfolding and leaf development spans approximately 4 weeks, during which the observations were carried out every day. The day of leaf unfolding was recorded when the first regular leaf surface became visible in 3-4 buds on the observed tree. This phase corresponds to the Biologische Bundesanstalt, Bundessortenamt und Chemische Industrie code 11 (BBCH11 - Meier 1997). The day of leaf colouring was recorded when at least 50\% of leaves had turned yellow on the observed tree (BBCH code 94). The day of leaf fall was recorded when at least $50 \%$ of the leaves had fallen from the tree crown (BBCH code 95).

(B) The Level II phenological monitoring network of the UNECE International Co-operative Programme on Assessment and Monitoring of Air Pollution Effects on Forests (ICP Forests - Fig. 1, blue triangles) in Slovenia (Vilhar et al. 2013b), where the selection of trees and the observations were made in accordance with the harmonised guidelines (Beuker et al. 2010, Vilhar et al. 2013a). Phenological monitoring was performed on 20 individual trees from each of 5 monitoring plots (phenological stations, $75 \times 75 \mathrm{~m}$ ). The assessments were always performed on the same trees. If one of the selected trees died or was removed, it was replaced with a nearby tree, in accordance with the criteria for phenological monitoring. All the selected trees were dominant or co-dominant, and the upper part of tree crowns was monitored using binoculars. If the upper part of the crown was not visible, the middle part of the crown was monitored. The same part of the crown was considered for subsequent phenological observations throughout the observation years. Biotic (pests and/or diseases) and abiotic damage (e.g., frost, wind, or hail) relevant to phenological development of trees was also considered. The observations during leaf unfolding, leaf colouring and leaf fall were performed weekly. The week of leaf unfolding was recorded when the first regular leaf surface became slightly visible in up to $33 \%$ of the observed part of the crown. The week of leaf colouring was recorded when coloured leaves in autumn became abundant in more than $66 \%$ of the monitored part of the crown. The week of leaf fall was recorded when leaves fell in autumn from the entire $(100 \%)$ observed part of the crown.

\section{Analysis}

It is worth emphasizing that NPN protocols were not specifically established to monitor tree phenology within the forest. Direct comparison of phenological observations from the two monitoring networks is unfeasible because of differences in spatial distribution of phenological stations and the number of observed trees per station. Therefore, two different models were tested to predict first leaf unfolding, general leaf colouring and leaf fall of beech in forests, using NPN phenological observations as the training dataset and the ICP Forests phenological observation as validation dataset. To overcome the differences in the observation time-step of the first leaf unfolding, general leaf colouring and leaf fall from the two phenological networks, the week of the year (WOY) was calculated from the daily phenological observations in the NPN dataset, similarly to the ICP Forests weekly observation dataset. 
In order to predict WOY for selected phenological phases, two models with different sets of variables were built based on the NPN phenological observations data using a general linear mixed model (GLMM):

- Model 1 was developed based on correlates of environmental variables at the NPN stations: altitude, slope (square root transformed), aspect ( $\mathrm{N}$ : north; NE: north-east; E: east; SE: south-east; S: south; SW: south-west; W: west; and NW: north-west) and year (2004 to 2010).

- Model 2 included the following independent variables: interpolated moving average of air temperature and number of sun hours (one, two or three months) at the NPN stations based on gridded meteorological data at $1 \mathrm{~km}$ resolution (Dolinar 2016). The months refer to the months before and the month during the phenological phase.

Model selection was performed as follows: for each of the models (model 1 and model 2) all combinations of the selected variables in a model were built. The Akaike Information Criterion (AIC) was used to select the best model (Burnham \& Anderson 2002), and the combinations of variables that were within four units of the AIC from the best performing combination of variables were averaged to one final model. As there were more phenological observations in each station, the station code was included in the GLMM as a random effect.

For the predictions of the phenological phases in forests, final models 1 and 2 were run using the data of the ICP Forests stations on slope, altitude, aspect, and observation year (model 1) or interpolated average monthly temperature and number of sun hours (model 2 ). The tree number ( 1 to 20) was nested into the ICP Forests station and included as a random effect. The predicted WOY of models for the phenological phases in forests were compared with the observed WOY of ICP Forests data using another GLMM. Models predictions were also compared to the NPN dataset to test the robustness of the models.

The performance of the models was evaluated based on the following statistics: $R^{2}$; Pearson correlation coefficient ( $r$ ), which describes the degree of correspondence between observed and predicted values; index of agreement $(D)$, which is a descriptive measure of relative error; and the root mean square error (RMSE), which expresses the error between the observed and predicted values (Thompson 1999). By comparing the indices ( $\left.R^{2}, r, D, R M S E\right)$ of the models 1 and 2, which predict phenological phases at NPN stations and in forests, respectively, we can evaluate how well the NPN data can predict tree phenological phases in forests.

\section{Results}

First leaf unfolding

On average, the first leaf unfolding was

Tab. 1 - Independent variables included in model 1 explaining the first leaf unfolding, general leaf colouring and leaf fall in European beech at the NPN phenological stations from 2004-2010. The estimates were averaged from the models that were four Akaike Information Criterion (AIC) units from the best model. The classes were compared with the first class in the variable (year=2004; aspect=East). Slope was square root transformed. (WOY): week of the year; (SE): standard error.

\begin{tabular}{|c|c|c|c|c|c|c|}
\hline $\begin{array}{l}\text { Dependent } \\
\text { variable }\end{array}$ & $\begin{array}{l}\text { Independent } \\
\text { variable }\end{array}$ & Estimate & SE & $\begin{array}{l}\text { Adjusted } \\
\text { SE }\end{array}$ & $\begin{array}{c}z \\
\text { value }\end{array}$ & $\operatorname{Pr}(>|z|)$ \\
\hline \multirow{9}{*}{$\begin{array}{l}\text { First leaf } \\
\text { unfolding } \\
\text { (WOY) }\end{array}$} & (Intercept) & 16.16 & 0.24 & 0.24 & 66.54 & $<0.001$ \\
\hline & year: 2005 & 0.15 & 0.13 & 0.13 & 1.14 & 0.250 \\
\hline & year: 2006 & -0.13 & 0.13 & 0.13 & 0.98 & 0.327 \\
\hline & year: 2007 & -2.19 & 0.13 & 0.13 & 16.84 & $<0.001$ \\
\hline & year: 2008 & -1.15 & 0.14 & 0.14 & 8.40 & $<0.001$ \\
\hline & year: 2009 & -1.69 & 0.13 & 0.13 & 12.81 & $<0.001$ \\
\hline & year: 2010 & -0.40 & 0.13 & 0.13 & 2.97 & 0.003 \\
\hline & altitude & 0.00 & 0.00 & 0.00 & 5.64 & $<0.001$ \\
\hline & sqrt(slope) & -0.10 & 0.05 & 0.06 & 1.84 & 0.066 \\
\hline \multirow{16}{*}{$\begin{array}{l}\text { General leaf } \\
\text { colouring } \\
\text { (WOY) }\end{array}$} & (Intercept) & 42.16 & 0.42 & 0.43 & 99.05 & $<0.001$ \\
\hline & year: 2005 & 0.01 & 0.21 & 0.21 & 0.07 & 0.944 \\
\hline & year: 2006 & 0.31 & 0.21 & 0.21 & 1.49 & 0.136 \\
\hline & year: 2007 & -1.82 & 0.22 & 0.22 & 8.20 & $<0.001$ \\
\hline & year: 2008 & -1.59 & 0.27 & 0.27 & 5.94 & $<0.001$ \\
\hline & year: 2009 & -0.22 & 0.22 & 0.22 & 1.01 & 0.314 \\
\hline & year: 2010 & -0.49 & 0.23 & 0.23 & 2.17 & 0.030 \\
\hline & aspect: flat & -0.74 & 0.64 & 0.66 & 1.12 & 0.263 \\
\hline & aspect: $\mathrm{N}$ & -1.19 & 0.62 & 0.64 & 1.85 & 0.065 \\
\hline & aspect: NE & 0.71 & 0.76 & 0.78 & 0.91 & 0.363 \\
\hline & aspect: NW & -0.30 & 0.74 & 0.76 & 0.39 & 0.693 \\
\hline & aspect: S & -1.26 & 0.55 & 0.57 & 2.22 & 0.027 \\
\hline & aspect: SE & -0.60 & 0.60 & 0.62 & 0.97 & 0.332 \\
\hline & aspect: SW & -0.12 & 0.69 & 0.71 & 0.18 & 0.861 \\
\hline & aspect: W & -0.24 & 0.57 & 0.59 & 0.41 & 0.684 \\
\hline & sqrt(slope) & 0.11 & 0.12 & 0.13 & 0.89 & 0.372 \\
\hline \multirow{15}{*}{$\begin{array}{l}\text { Leaf fall } \\
\text { (WOY) }\end{array}$} & (Intercept) & 43.63 & 0.25 & 0.25 & 174.74 & $<0.001$ \\
\hline & year: 2005 & 0.00 & 0.19 & 0.19 & 0.03 & 0.980 \\
\hline & year: 2006 & 0.54 & 0.19 & 0.19 & 2.80 & 0.005 \\
\hline & year: 2007 & -1.26 & 0.24 & 0.24 & 5.14 & $<0.001$ \\
\hline & year: 2008 & -1.26 & 0.27 & 0.27 & 4.64 & $<0.001$ \\
\hline & year: 2009 & 0.44 & 0.20 & 0.20 & 2.16 & 0.031 \\
\hline & year: 2010 & -0.22 & 0.21 & 0.21 & 1.06 & 0.289 \\
\hline & aspect: flat & -0.31 & 0.58 & 0.60 & 0.51 & 0.607 \\
\hline & aspect: N & -0.44 & 0.58 & 0.60 & 0.75 & 0.455 \\
\hline & aspect: NE & 1.28 & 0.7 & 0.72 & 1.78 & 0.075 \\
\hline & aspect: NW & 0.15 & 0.67 & 0.70 & 0.22 & 0.825 \\
\hline & aspect: $\mathrm{S}$ & -0.66 & 0.5 & 0.52 & 1.26 & 0.206 \\
\hline & aspect: SE & 0.39 & 0.54 & 0.56 & 0.69 & 0.488 \\
\hline & aspect: SW & 0.45 & 0.63 & 0.65 & 0.70 & 0.486 \\
\hline & aspect: W & -0.08 & 0.52 & 0.54 & 0.14 & 0.885 \\
\hline
\end{tabular}

recorded in the $16^{\text {th }}$ week of the year $(16.4$ WOY, mid-April). The earliest first leaf unfolding was recorded in 2007 (14.9 WOY), while the latest in 2005 (17.2 WOY). For model 1 , the first leaf unfolding showed high positive correlation with altitude in all models (weight $\mathrm{Wi}=1.00-$ Tab. 1). A trend was detected between the slope and the date of first leaf unfolding, though it was non-significant and has been found only in a few models $(\mathrm{Wi}=0.21)$. The year of observation was an important variable explaining the date of leaf unfolding in all models $(\mathrm{Wi}=1.00)$. For model 2 , the first leaf unfolding showed high negative correlation with the average temperature from the months February, March and April $(\mathrm{Wi}=1)$ and the number of sun hours in April (Wi =
0.28 - Tab. 2). As expected, both models predicted well the date of first leaf unfolding in open areas (Tab. 3). Predictions of the date of first leaf unfolding in the forest were slightly better by model 2 compared to model 1 (Fig. 2, Tab. 3) with relatively higher $R^{2}$ ( 0.45 vs. 0.40 for model 2 vs. model 1 , respectively), higher $r$ ( $0.78 \mathrm{vs}$. 0.63 ) and lower D (0.75 vs. 0.70, respectively). The RMSE between the observed and predicted first leaf unfolding in the forest was similar for both models (1.1 WOY). Furthermore, there were no significant differences between the observed date of first leaf unfolding in the forest and model predictions (for model 1: $t=0.344, \mathrm{P}=$ 0.731 ; for model 2 : $t=-0.912, P=0.362$ ). 
Tab. 2 - Independent variables included in model 2 explaining the first leaf unfolding, general leaf colouring and leaf fall of European beech at the NPN phenological stations from 2004-2010. The estimates were averaged from the models that were four Akaike Information Criterion (AIC) units from the best model. (WOY): week of the year; (SE): standard error.

\begin{tabular}{|c|c|c|c|c|c|c|}
\hline $\begin{array}{l}\text { Dependent } \\
\text { variable }\end{array}$ & Independent variable & Estimate & $\begin{array}{l}\text { Std. } \\
\text { Error }\end{array}$ & $\begin{array}{l}\text { Adjusted } \\
\text { SE }\end{array}$ & $\begin{array}{c}\mathrm{Z} \\
\text { value }\end{array}$ & $\operatorname{Pr}(>|z|)$ \\
\hline \multirow{3}{*}{$\begin{array}{l}\text { First leaf } \\
\text { unfolding (WOY) }\end{array}$} & (Intercept) & 19.58 & 0.21 & 0.21 & 93.67 & $<0.001$ \\
\hline & Average temperature in April, March and February & -0.55 & 0.04 & 0.04 & 12.35 & $<0.001$ \\
\hline & No of sun hours in April & -0.004 & 0.001 & 0.001 & 3.56 & $<0.001$ \\
\hline \multirow{2}{*}{$\begin{array}{l}\text { General leaf } \\
\text { colouring (WOY) }\end{array}$} & (Intercept) & 36.46 & 0.64 & 386.00 & 56.80 & $<0.001$ \\
\hline & Average temperature in September and October & 0.43 & 0.05 & 386.00 & 8.62 & $<0.001$ \\
\hline \multirow[t]{2}{*}{ Leaf fall (WOY) } & (Intercept) & 37.91 & 0.67 & 208.00 & 56.84 & $<0.001$ \\
\hline & Average temperature in September & 0.39 & 0.04 & 208.00 & 8.66 & $<0.001$ \\
\hline
\end{tabular}

Tab. 3 - Performance assessment of model 1 and model 2 based on $R^{2}$, Pearson correlation coefficient ( $r$ ), index of agreement (D) and the root mean square error (RMSE) between model predictions and observed phenological phases in European beech at phenological stations (NPN) and in the forest (ICP Forests). (WOY): week of the year.

\begin{tabular}{|c|c|c|c|c|c|c|c|c|c|}
\hline \multirow{2}{*}{$\begin{array}{l}\text { Phenological } \\
\text { phases }\end{array}$} & \multirow{2}{*}{ Model } & \multicolumn{2}{|l|}{$\mathrm{R}^{2}$} & \multicolumn{2}{|l|}{$r$} & \multicolumn{2}{|l|}{ D } & \multicolumn{2}{|c|}{ RMSE (WOY) } \\
\hline & & NPN & ICP Forests & NPN & ICP Forests & NPN & ICP Forests & NPN & ICP Forests \\
\hline \multirow{2}{*}{$\begin{array}{l}\text { First leaf } \\
\text { unfolding }\end{array}$} & Model 1 & 0.56 & 0.40 & 0.77 & 0.63 & 0.85 & 0.75 & 0.8 & 1.1 \\
\hline & Model 2 & 0.68 & 0.45 & 0.83 & 0.78 & 0.89 & 0.70 & 0.7 & 1.1 \\
\hline \multirow{2}{*}{$\begin{array}{l}\text { General leaf } \\
\text { colouring }\end{array}$} & Model 1 & 0.33 & -1.12 & 0.58 & 0.20 & 0.70 & 0.47 & 1.3 & 1.8 \\
\hline & Model 2 & 0.50 & 0.15 & 0.71 & 0.60 & 0.79 & 0.54 & 1.2 & 1.6 \\
\hline \multirow[t]{2}{*}{ Leaf fall } & Model 1 & 0.31 & 0.23 & 0.56 & 0.51 & 0.66 & 0.66 & 1.2 & 1.4 \\
\hline & Model 2 & 0.61 & -0.12 & 0.80 & 0.63 & 0.86 & 0.57 & 0.9 & 1.6 \\
\hline
\end{tabular}

Fig. 2 - Comparison between the predicted and observed week of the year (WOY) of the phenological phases in European beech at phenological stations in the forest (ICP Forests). (a) First leaf unfolding date; (b) general leaf colouring date; (c) leaf fall date; $\left({ }^{*}\right)$ : $\mathrm{P}<0.05 ;(* *): \mathrm{P}<0.01$ $(* * *): P<0.001$

a) first leaf unfolding

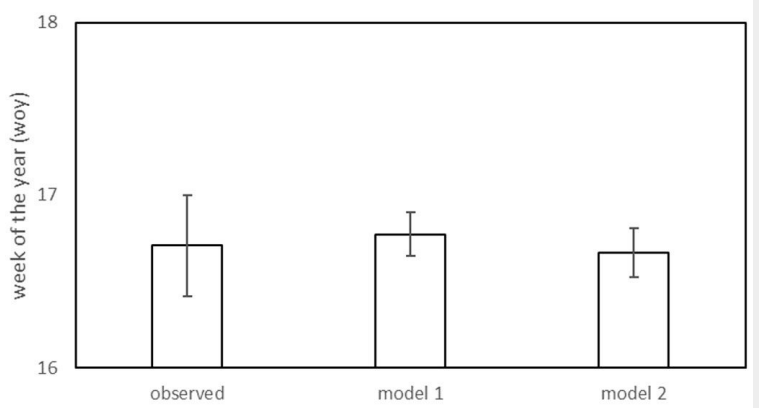

b) general leaf colouring

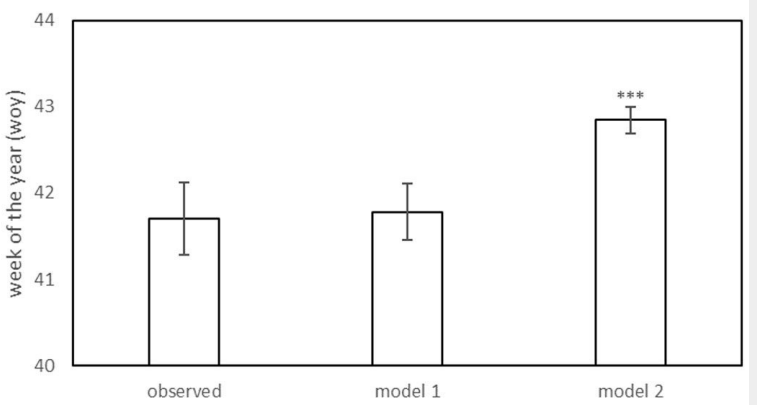

c) leaf fall

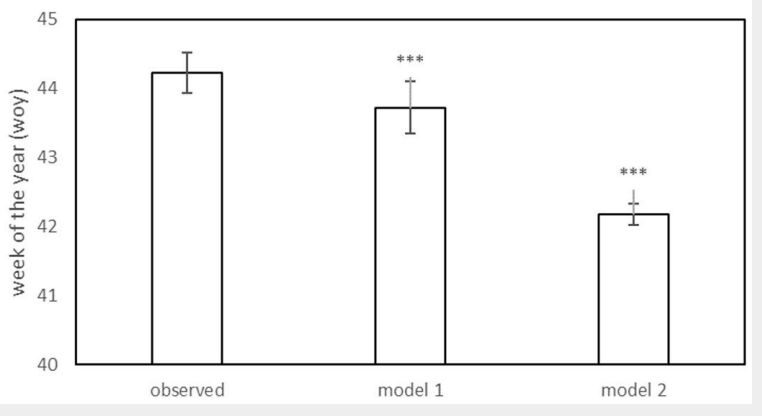

\section{General leaf colouring}

On average, the general leaf colouring was recorded in the $41^{\text {st }}$ week (41.4 WOY early October). In model 1 , the general leaf colouring was highly influenced by the year of observation ( $\mathrm{Wi}=1$ - Tab. 1). The earliest date of leaf colouring was observed in 2007 (40.0 WOY), while the latest was observed in 2006 (42.2 WOY). Aspect was another important variable explaining general leaf colouring, but contributed little to the averaged model $(\mathrm{Wi}=0.52-\mathrm{Tab} .1)$. In general, the earliest leaf colouring occurred at stations with southern aspect (40.7 WOY), while it was latest at stations with a north-eastern aspect (42.8 WOY). The general leaf colouring was not significantly related to the slope $(z=0.893, P=$ 0.372 ), and did not contribute significantly to the averaged model $(\mathrm{Wi}=0.07)$. For model 2, the general leaf colouring showed positive correlation to average monthly temperature in September and October (Tab. 2). Both models satisfactorily predicted general leaf colouring dates in open areas (Tab. 3), with slightly better predictions for model 2 compared to model 1 . However, the fit was lower compared to the first leaf unfolding. The leaf colouring in the forest was not predicted satisfactorily by model 1 (Tab. 3). The difference between the predicted general leaf colouring in forest by model 1 and that observed was not statistically significant $(t=0.515, P=$ 0.607 ). Model 2 predictions were better compared to model 1 , but still not satisfactory (Tab. 3). Model 2 predicted the leaf colouring in forest later than it was observed $(t=17.48, P<0.001-$ Fig. $2 b)$. 
Leaf fall

On average, the leaf fall started at the $43^{\text {th }}$ week of the year ( 43.46 WOY, late October). In model 1 , the leaf fall was strongly affected by the year of observation $(\mathrm{Wi}=1$ - Tab. 1). The earliest leaf fall was in 2007, occurring in the $41^{\text {st }}$ week (41.95), while the latest was in 2009 (43.95 WOY). The earliest leaf fall dates were at the stations with southern aspects in the $42^{\text {nd }}$ week (42.77 WOY). The latest leaf fall was at the stations with north-eastern aspects (44.83 WOY). Leaf fall at phenological stations with an eastern aspect was later when compared to either flat areas or other aspects, though not significantly different. However, aspect scarcely contributed to the averaged model $(\mathrm{Wi}=0.22)$. For model 2 , the leaf fall date showed a positive correlation to the average temperature in September (Tab. 2).

Both models satisfactorily predicted leaf fall in open areas (Tab. 3), with better predictions for model 2 compared to model 1. However, the fit was lower compared to the first leaf unfolding. The leaf fall in the forest was satisfactorily predicted by model 1 (Tab. 3). However, model 1 predictions of leaf fall in the forest were earlier than that observed $(t=-8.287, P<0.001)$. Model 2 predictions of leaf fall in the forest were worse compared to model 1 and unsatisfactory (Tab. 3). Model 2 predicted leaf fall in the forest even earlier than model 1 ( $t=$ -31.94, $\mathrm{P}<0.001-$ Fig. $2 \mathrm{C}$ ).

\section{Discussion}

Beech phenology is generally considered to be less sensitive to environmental variability than some other tree species (Estrella \& Menzel 2006, Davi et al. 2011, Vitasse et al. 2011). This study demonstrates that first leaf unfolding dates in beech can be satisfactorily predicted based on tree phenological phases observed at national phenological stations. For general leaf colouring the predictions were not satisfactory, whereas for the leaf fall only predictions of the model using correlates of environmental variables at phenological stations were satisfactory; however, the fit was lower compared to the first leaf unfolding.

First leaf unfolding in beech is strongly related to temperature (Menzel 2000, Menzel et al. 2006) and photoperiod (Caffarra \& Donnelly 2011). It seems to be less sensitive to micro-topographical factors, as reported by Davi et al. (2011) in France where the first leaf unfolding of beech did not significantly differ between northern and southern aspects in 2007, though showing a high year-to-year variability. This suggests that factors at a macroecological scale, such as altitude, are mainly affecting the beech first leaf unfolding (Cufar et al. 2012). The results of this study show that first leaf unfolding of beech in forest habitats could be predicted based on phenological observations at national phenological stations. The developed model, based on interpolated monthly air temperature and sun hours, allows application over a large range of possible weather conditions (e.g., regional, European). Nevertheless, when only on-site data on environmental correlates at phenological stations are available (e.g., altitude, slope, aspect), regionally-limited but satisfactory predictions of first leaf unfolding of beech in forest could be expected.

In contrast to first leaf unfolding, the environmental factors driving autumn phenological events, such as leaf colouring or leaf fall, are less well understood (Delpierre et al. 2009, Lebourgeois et al. 2010, Vitasse et al. 2011). The main drivers of general leaf colouring of beech are supposed to be both photoperiod and low temperatures, contributing to the smaller year-to-year variability observed (Dufrene et al. 2005, Vitasse et al. 2011). The results of this study, however, indicate a high sensitivity of general leaf colouring to the year of observation. General leaf colouring of beech in forests could not be satisfactorily predicted by any of the models applied. Predictions of the model based on interpolated monthly air temperature and sun hours at phenological stations were slightly better compared to predictions of the model based on environmental correlates; however, the predicted leaf colouring in forest was later than that observed. One of the reasons might be the difficulty to accurately acquire leaf senescence observations (Estrella \& Menzel 2006). Indeed, the phenological phase "leaf colouring" is obviously more problematic to be recognised than the first three green leaves in spring, as the definition refers to $50 \%$ of all coloured leaves, including leaves both on branches and on the ground. The variation among individual trees at comparable or identical sites is much higher than in first leaf unfolding. Moreover, in this study local site conditions at phenological stations related to soil properties and radiation were not undertaken due to the lack of relevant auxiliary data.

The leaf fall in the forest was satisfactorily predicted only by the model based on site-dependent environmental correlates, revealing a weak sensitivity to site aspect. However, leaf fall in the forest was predicted to occur 1.4 WOY (about 10 days) later than that observed. Nonetheless, our results show that beech leaf fall in forest habitats could be predicted based on phenological observations at national phenological stations using the model based on environmental correlates at phenological stations (e.g., altitude, slope, aspect). Contrastingly, predictions of the model based on interpolated monthly air temperature and hours of sun were not satisfactory, though they could be improved by on-site measurements of climatic data (e.g., air temperature, solar radiation, etc. - Vilhar et al. 2014).

Further factors affecting predictions of beech phenology in forests can be ex- plained by the two phenological networks and protocols which were different in several features. First, the phenological phases of the NPN network were recorded daily, and the whole tree crown was monitored (Koch et al. 2007). In contrast, the phenological phases of the ICP Forests network were monitored weekly, and only the upper or middle part of the crown was observed (Beuker et al. 2010). In this study, the differences in the observation timestep were overcome by synchronising the observations through WOY. Another difference between the NPN and the ICP Forests datasets was the number of trees observed per phenological station. In the NPN network, monitoring of different phenological phases is performed on a single tree, whereas 20 trees are observed in the ICP Forests stations. Our results show a large variation in the weekf of the year (WOY) observed for the trees within the ICP Forests station for the phenological phases investigated. Thus, the NPN network reflects the phenological behaviour of a single tree, which may not be necessarily representative of the larger region surrounding the phenological station, as suggested by the national Guidelines for Phenological Observations (Zust 2015). Vitasse et al. (2009) reported high variation in the sensitivity to temperature of beech leaf phenology within populations. On the other hand, the phenological observations from 20 trees at the ICP Forests stations are likely to better represent the phenology of the local tree population. Another important difference between the monitoring networks were the local site characteristics of the phenological stations. Indeed, the NPN phenological monitoring network uses trees in open areas and on the forest edge, whereas ICP Forests monitors trees within forest stands in larger forest complexes. Due to the direct influence of open-field temperatures and solar radiation in open areas or at forest edges (Morecroft et al. 1998) and less pronounced temperature extremes within forest stands or in the canopy (Mildrexler et al. 2011), lower agreement between beech phenology at phenological stations in open areas or in the forest would be expected.

Interestingly, the differences between the phenological observations in forests and the model predictions were not consistent among phenological phases and years. High inter-annual variation in beech phenology has been reported by several authors (Lopez et al. 2008, Davi et al. 2011). As beech shows a high phenotypic plasticity in leaf phenology, it reacts directly to temperature changes (Vitasse et al. 2010), which could be reflected in changes in the phenological phases among years. However, the inter-annual differences in the phenological observations in forests and the model predictions could be due to inaccurate prediction by model 1. In Sweden, inter-annual variation in tree phenology was also modelled for different bioclimatic 
regions (Olsson et al. 2013), with most of the models inaccurately predicting the inter-annual variation. In this study, the combination of local site characteristics (e.g., weather, temperature) with differences among beech provenances across sites could partially account for the unsatisfactory predictions of the model and the variation of phenological observations among years.

\section{Conclusions}

This study shows that the models satisfactorily predicted the first leaf unfolding and leaf fall dates of beech in selected forest habitats, while general leaf colouring was less accurately predicted. Especially in areas with complex terrain, models are prone to incorrectly predict phenological phases (Olsson et al. 2013). Therefore, we recommend combining ICP Forests and NPN methodologies to improve the national phenological network. First, more trees should be monitored per phenological station to decrease the effect of individual variability on the phenological assessment. Second, observations should be carried out every day to improve the temporal resolution of datasets. Third, the forest phenological stations should be more evenly distributed along the altitudinal range of the natural forest habitats of the tree species under study. Finally, measurement of climatic data should be performed at phenological stations established in complex terrains to overcome the limitations of spatial interpolated data. The results of the models presented in this study could also be tested on other tree species at a larger scale.

\section{Acknowledgements}

The authors would like to acknowledge the financial support from the following sources: the Slovenian Research Agency (research core funding No. 0404-501; the Programme Group "Forest biology, ecology and technology"), ICP Forests and the Forest monitoring in Slovenia, the ManFor C.BD project "Managing forests for multiple purposes: carbon, biodiversity and socio-economic wellbeing" (LIFEogENV/IT/00 0078) and EUFORINNO "European Forest Research and Innovation" (Reg. Pot No. 315982). We would like to thank Jean McCollister for proofreading the manuscript. In addition, we thank the reviewers for their helpful comments on the manuscript.

The first two authors (U.V. and M.D.G.) have contributed equally to the article.

\section{References}

Aono Y, Kazui K (2008). Phenological data series of cherry tree flowering in Kyoto, Japan, and its application to reconstruction of springtime temperatures since the $9^{\text {th }}$ century. International Journal of Climatology 28: 905-914. - doi: 10.1002/joc.1594

Bale JS, Masters GJ, Hodkinson ID, Awmack C, Bezemer TM, Brown VK, Butterfield J, Buse A, Coulson JC, Farrar J, Good JEG, Harrington R,
Hartley S, Jones TH, Lindroth RL, Press MC, Symrnioudis I, Watt AD, Whittaker JB (2002). Herbivory in global climate change research: direct effects of rising temperature on insect herbivores. Global Change Biology 8: 1-16. - doi: 10.1046/j.1365-2486.2002.00451.x

Bertin RI (2008). Plant phenology and distribution in relation to recent climate change. The Journal of the Torrey Botanical Society 135: 126146. - doi: 10.3159/07-RP-035R.1

Beuker E, Raspe S, Bastrup-Birk A, Preuhsler T (2010). Phenological observations. Part VI. United Nations Economic Commission for Europe Convention on Long-Range Transboundary Air Pollution, ICP Forests, Hamburg, Germany, pp. 15. [online] URL: http://www.icpforests.org/pdf/manual/2016/Manual_Part_VI.p df

Burnham KP, Anderson DR (2002). Model selection and multimodel inference: a practical information - Theoretic approach. Springer-Verlag, London, UK, pp. 351. - doi: 10.1007/b97636

Caffarra A, Donnelly A (2011). The ecological significance of phenology in four different tree species: effects of light and temperature on bud burst. International Journal of Biometeorology 55: 711-721. - doi: 10.1007/s00484-010-038 6-1

Chen X, Xu L (2012). Temperature controls on the spatial pattern of tree phenology in China's temperate zone. Agricultural and Forest Meteorology 154-155: 195-202. - doi: 10.1016/j.agrfor met.2011.11.006

Chuine I, Yiou P, Viovy N, Seguin B, Daux V, Ladurie $E$ (2004). Historical phenology: grape ripening as a past climate indicator. Nature 432: 289-290. - doi: 10.1038/432289a

Cufar K, De Luis M, Saz M, Crepinšek Z, KajfezBogataj $L$ (2012). Temporal shifts in leaf phenology of beech (Fagus sylvatica) depend on elevation. Trees - Structure and Function 26: 10911100. - doi: 10.1007/s00468-012-0686-7

Davi H, Gillmann M, Ibanez T, Cailleret M, Bontemps A, Fady B, Lefèvre F (2011). Diversity of leaf unfolding dynamics among tree species: new insights from a study along an altitudinal gradient. Agricultural and Forest Meteorology 151: 1504-1513. - doi: 10.1016/j.agrformet.2011.06. 008

Delpierre N, Dufrêne E, Soudani K, Ulrich E, Cecchini S, Boé J, François C (2009). Modelling interannual and spatial variability of leaf senescence for three deciduous tree species in France. Agricultural and Forest Meteorology 149: 938-948. - doi: 10.1016/j.agrformet.2008.11. 014

Dittmar C, Elling W (2006). Phenological phases of common beech (Fagus sylvatica L.) and their dependence on region and altitude in Southern Germany. European Journal of Forest Research 125: 181-188. - doi: 10.1007/s10342-005-0099-x Doi H, Katano I (2008). Phenological timings of leaf budburst with climate change in Japan. Agricultural and Forest Meteorology 148: 512516. - doi: 10.1016/j.agrformet.2007.10.002

Dolinar M (2016). Monthly gridded datasets for temperature and precipitation over Slovenia. Geostatistisc and Machine Learning (GeoMLA), Applications in Climate and Environmental Sciences, DHMZ, SEA, GFUB, Belgrade, Serbia, pp. 50-55. [online] URL: http://geomla.grf.bg.ac.
rs/site_media/static/presentations/day_2/4/GEO MLA2016_Dolinar.pdf

Donnelly $\bar{A}$, Jones M, Sweeney J (2004). A review of indicators of climate change for use in Ireland. International Journal of Biometeorology 49: 1-12. - doi: 10.1007/s00484-004-0215-5 Donnelly A, Caffarra A, O'Neill B (2011). A review of climate-driven mismatches between interdependent phenophases in terrestrial and aquatic ecosystems. International Journal of Biometeorology 55: 805-817. - doi: 10.1007/s00484-011-04 26-5

Dufrene E, Davi H, Francois C, Maire GL, Dantec VL, Granier A (2005). Modelling carbon and water cycles in a beech forest: Part I. Model description and uncertainty analysis on modelled NEE. Ecological Modelling 185: 407-436. doi: 10.1016/j.ecolmodel.2005.01.004

Estrella N, Menzel A (2006). Responses of leaf colouring in four deciduous tree species to climate and weather in Germany. Climate Research 32: 253-267. - doi: 10.3354/cro32253

IPCC (2013). Climate change 2013: the physical science basis. Contribution of Working Group I to the Fifth Assessment Report of the Intergovernmental Panel on Climate Change. Cambridge University Press, Cambridge, UK and New York, NY, USA, pp. 1535.

Koch E, Bruns E, Chmielewsk FM, Defila C, Lipa W, Menzel A (2007). Guidelines for phenological observations. WMO Technical Commission for Climatology, Open Program Area Group on Monitoring and Analysis of Climate Variability and Change (OPAG2), pp. 39. [online] URL: http://blogs.nwic.edu/herbariumblog/files/2011/ 08/guidelines-ges-fin 2.pdf

Kutnar L, Zupančič M, Robič D, Zupančič N, Zitnik S, Kralj T, Tavčar I, Dolinar M, Zrnec C, Kraigher H (2002). Razmejitev provenienčnih območij gozdnih drevesnih vrst $v$ Sloveniji na osnovi ekoloških regij [Delimitation of provenance regions of forest tree species in Slovenia based on ecological regions]. Zbornik gozdarstva in lesarstva 67: 73-117. [in Slovenian]

Lebourgeois F, Pierrat J-C, Perez V, Piedallu C, Cecchini $S$ (2010). Simulating phenological shifts in French temperate forests under two climatic change scenarios and four driving global circulation models. International Journal of Biometeorology 54: 563-581. - doi: 10.1007/ s00484-010-0305-5

Lenoir J, Gégout JC, Marquet PA, De Ruffray P, Brisse $H$ (2008). A significant upward shift in plant species optimum elevation during the 20th century. Science 320: 1768-1771. - doi: 10.1126/science.1156831

Lopez OR, Farris-Lopez K, Montgomery RA, Givnish JT (2008). Leaf phenology in relation to canopy closure in southern Appalachian trees. American Journal of Botany 95 (11): 1395-1407. doi: 10.3732/ajb.0800104

Luis M, Cufar K, Saz M, Longares L, Ceglar A, Kajfez-Bogataj L (2014). Trends in seasonal precipitation and temperature in Slovenia during 1951-2007. Regional Environmental Change 14: 1801-1810. - doi: 10.1007/s10113-012-0365-7 Meier U (1997). Growth stages of mono- and dicotyledonous plants. Blackwell Wissenschafts-Verlag, Berlin, Boston, pp. 622.

Menzel A (2000). Trends in phenological phases in Europe between 1951 and 1996. International 
Journal of Biometeorology 44: 76-81. - doi: 10.1007/s004840000054

Menzel A, Sparks TH, Estrella N, Koch E, Aasa A, Ahas R, Alm-Kübler K, Bissolli P, Braslavská OG, Briede A, Chmielewski FM, Crepinsek Z, Curnel Y, Dahl A, Defila C, Donnelly A, Filella Y, Jatczak K, Måge F, Mestre A, Nordli O, Peñuelas J, Pirinen $P$, Remisová $V$, Scheifinger $H$, Striz $M$, Susnik A, Van Vliet AJH, Wielgolaski F-E, Zach S, Zust $A$ (2006). European phenological response to climate change matches the warming pattern. Global Change Biology 12: 1969-1976. - doi: 10.1111/j.1365-2486.2006.01193.x

Mildrexler DJ, Zhao M, Running SW (2011). A global comparison between station air temperatures and MODIS land surface temperatures reveals the cooling role of forests. Journal of Geophysical Research 116 (G3): 245. - doi: 10.102 9/2010JG001486

Morecroft MD, Taylor ME, Oliver HR (1998). Air and soil microclimates of deciduous woodland compared to an open site. Agricultural and Forest Meteorology 90: 141-155. - doi: 10.1016/SO1 68-1923(97)00070-1

Olsson C, Bolmgren K, Lindström J, Jönsson AM (2013). Performance of tree phenology models along a bioclimatic gradient in Sweden. Ecological Modelling 266: 103-117. - doi: 10.1016/j.ecol model.2013.06.026

Parmesan C (2006). Ecological and evolutionary responses to recent climate change. Annual Review of Ecology, Evolution and Systematics 37: 637-669. - doi: 10.1146/annurev.ecolsys.37. 091305.110100

Pellerin M, Delestrade A, Mathieu G, Rigault O, Yoccoz N (2012). Spring tree phenology in the Alps: effects of air temperature, altitude and local topography. European Journal of Forest Research 131: 1957-1965. - doi: 10.1007/s10342012-0646-1

Thompson SA (1999). Hydrology for water man- agement. Balkema, Rotterdam, The Netherlands, pp. 476. [online] URL: http://www.cabdi rect.org/cabdirect/abstract/19991907322

Tylianakis JM, Didham RK, Bascompte J, Wardle DA (2008). Global change and species interactions in terrestrial ecosystems. Ecology Letters 11: 1351-1363. - doi: 10.1111/j.1461-0248.2008.012 50.x

Van Asch M, Visser ME (2007). Phenology of forest caterpillars and their host trees: the importance of synchrony. Annual Review of Entomology 52: 37-55. - doi: 10.1146/annurev.ento.52.11 0405.091418

Vilhar U, Beuker E, Mizunuma T, Skudnik M, Lebourgeois F, Soudani K, Wilkinson M (2013a). Chapter 9. Tree Phenology. In: "Forest Monitoring: Methods for terrestrial investigations in Europe with an overview of North America and Asia" (M Ferretti, R Fischer eds). Elsevier, Amsterdam, Netherlands, vol. 12, pp. 169-182. [online] URL: http://books.google.com/books? id=bzXPCwAAQBAJ

Vilhar U, Skudnik M, Simončič P (2013b). Fenološke faze dreves na ploskvah intenzivnega monitoringa gozdov $v$ Sloveniji [Phenological phases of trees in intensive monitoring plots in Slovenia]. Acta Silvae et Ligni 100: 5-17. [in Slovenian] - doi: 10.20315/ASetL.100.1

Vilhar U, Skudnik M, Ferlan M, Simončič P (2014). Vpliv vremenskih spremenljivk in osutosti krošenj na fenološke faze dreves na ploskvah intenzivnega monitoringa gozdnih ekosistemov $v$ Sloveniji [Influence of meteorological conditions and crown defoliation on tree phenology in intensive forest monitoring plots in Slovenia]. Acta Silvae et Ligni 105: 1-15. [in Slovenian] - doi: 10.20315/ASetL.105.1

Vitasse $\mathrm{Y}$, Delzon S, Dufrêne E, Pontailler J-Y, Louvet J-M, Kremer A, Michalet R (2009). Leaf phenology sensitivity to temperature in European trees: Do within-species populations ex- hibit similar responses? Agricultural and Forest Meteorology 149: 735-744. - doi: 10.1016/j.agrfor met.2008.10.019

Vitasse Y, Bresson CC, Kremer A, Michalet R, Delzon S (2010). Quantifying phenological plasticity to temperature in two temperate tree species. Functional Ecology 24: 1211-1218. - doi: 10.1111/j.1365-2435.2010.01748.x

Vitasse Y, François C, Delpierre N, Dufrêne E, Kremer A, Chuine I, Delzon S (2011). Assessing the effects of climate change on the phenology of European temperate trees. Agricultural and Forest Meteorology 151: 969-980. - doi: 10.1016/ j.agrformet.2011.03.003

Vliet AH, Groot R, Bellens $\mathrm{Y}$, Braun P, Bruegger R, Bruns E, Clevers J, Estreguil C, Flechsig $M$, Jeanneret F, Maggi M, Martens P, Menne B, Menzel A, Sparks T (2003). The European phenology network. International Journal of Biometeorology 4: 202-212. - doi: 10.1007/s00484003-0174-2

Zust A (2015). Fenologija v Sloveniji: Priročnik za fenološka opazovanja [Phenology in Slovenia: Manual for phenological observations]. Ministry of Environment, Slovenian Environment Agency, Ljubljana, Slovenia, pp. 104. [in Slovenian]

\section{Supplementary Material}

Tab. S1 - Phenological stations of the Slovenian National Phenological Network of the Slovenian Environment Agency (NPN).

Tab. S2 - Phenological stations of the International Co-operative Programme on Assessment and Monitoring of Air Pollution Effects on Forests (ICP Forests) network in Slovenia.

Link: Vilhar_1820@supploo1.pdf 